\title{
PERLUNYA PERUBAHAN PARADIGMA DARI NEW PUBLIC MANAGEMENT KE NEW PUBLIC GOVERNANCE DI INDONESIA
}

\author{
Muchamad Zaenuri \\ Fakultas Isipol Universitas Muhammdiyah Yogyakarta
}

\begin{abstract}
Innovation in the process and services of local government should be dynamic and firmly based on a clear conceptual foundation guaranteed by law. In will be not a long time to wait till the local governments may enjoy certain degree of freedom to initiate an innovation, since the draft or the bill on Local Governement grants such opportunity. Considering that innivation in the process and services of the government facing many barriers, it is needed therefore, not merely legal bases, but also the conceptual basis (paradigm) must be well formulated. The paradigm new public governance (NPG) which offers a concept of innivation based on the collaboration of three pillars of governance; goverment, private entities and society, seems to be prospective for being the basis of such innovation.
\end{abstract}

Key words : innovation, governance, local government.

\section{Pengantar}

Tidak lama lagi penyeleggaraan pemerintahan daerah di Indonesia memasuki babak baru karena rancangan undang-undang tentang Pemerintahan Daerah yang baru sudah memasuki tahap final dalam pembahasan dan rencananya akan disyahkan oleh DPR menjadi undang-undang selambat-lambatnya bulan April 2013 (Kompas, 27 Desember 2012). Setelah disyahkan oleh DPR nantinya undang-undang ini akan menggantikan Undang-undang Nomor 32 tahun 2004 yang dirasa sudah tidak sesuai lagi dengan perkembangan zaman, ketatanegaraan dan tuntutan penyelenggaraan pemerintahan yang semakin demokratis dan inovatif. Salah satu isu utama yang mendorong perlunya perubahan dalam Undang-undang Nomor 32 tahun 2004 adalah tidak adanya payung hukum terhadap inovasi-inovasi yang dilakukan oleh berbagai pemerintah daerah. Akibatnya banyak kepala daerah yang terpaksa berurusan dengan hukum dengan dakwaan pelanggaran administrasi meskipun kebijakan yang diambil terbukti membawa kebaikan dan kemajuan bagi daerah yang bersangkutan (Ruhyanto, 2012).

Banyak pemerintah daerah di Indonesia telah melakukan inovasi sejak mulai diberlakukannya kebijakan desentralisasi dan otonomi daerah melalui Undang-undang Nomor 22 tahun 1999 tentang Pemerintahan Daerah: Beberapa daerah secara sungguh-sungguh melakukan inovasi baik berupa perbaikan tata kelola pemerintahan, pelayanan publik, dan berbagai kebijakan yang ramah terhadap investasi dalam rangka untuk menggairahkan iklim usaha di daerah. Pada masa itu mulai berkembang isu bahwa pemerintah daerah dikatakan maju apabila mampu melakukan inovasi-inovasi dalam penyelenggaraan pemerintahan dan pemberian pelayanan kepada masyarakat.

Setelah kurang lebih 12 tahun diberlakukannya otonomi daerah ini sudah banyak pemerintah daerah melakukan inovasi dalam tata kelola maupun pelayanan kepada masyarakat dan peningkatan iklim usaha. Di bidang tata kelola banyak pemerintah daerah yang telah melakukan inovasi terutama yang berkaitan dengan pengembangan sistem transparansi penyelenggaraan pemerintahan, mekanisme penanganan aduan masyarakat, 
dan pengembangan forum-forum lintas stakeholders dalam rangka meningkatkan partisipasi masyarakat. Dalam aspek pelayanan publik, praktek inovasi banyak ditemukan di sektor pendidikan dan kesehatan dengan orientasi utama meningkatkan akses dan kualitas pelayanan (Ruhyanto, 2012). Untuk peningkatan iklim usaha banyak pemerintah daerah melakukan deregulasi aturan perijinan dan memperpendek rantai birokrasi serta menicptakan iklim usaha yang kondusif agar swasta dapat berperan aktif membantu menggerakkan roda perekonomian daerah. Beberapa daerah seperti Takalar, Bulukumba, Probolinggo, Pasuruan, Kota Depok, Gianyar, Sragen, Kota Yogyakarta, Kota Malang, merupakan sederetan daerah yang dikenal produktif melakukan terobosan-terobosan yang bersifat inovatif.

Untuk memberikan apresiasi kepada pemerintah daerah yang telah melakukan inovasi tersebut Kementrian Dalam Negeri secara rutin tiap tahun memberikan penghargaan berupa innovative government award (IGA) kepada pemerintah daerah dengan berbagai kategori. Untuk tahun 2011 yang lalu Kota Palembang termasuk yang memperoleh penghargaan untuk kategori Tata Kelola Pemerintahan, Kota Banjar untuk kategori Pelayanan Publik, Kota Semarang untuk kategori Pemberdayaan Masyarakat dan Kota Malang meraih terbaik untuk kategori Daya Saing Daerah (Kompas, 23 Desember 2011).

Seluruh upaya tersebut dilakukan dalam rangka untuk mendorong kinerja pemerintah daerah dalam percepatan pembangunan, meningkatkan akses maupun kualitas pelayanan publik, serta mendorong terciptanya iklim usaha yang kondusif yang bermuara pada peningkatan kesejahteraan masyarakat. Inovasi yang telah dilakukan banyak pemerintah daerah sebentar lagi akan memperoleh payung hukum-nya. Sehingga kepala daerah tidak lagi takut untuk membuat terobosan-terobosan untuk melakukan inovasi yang pada akhirnya diharapkan dapat meningkatkan kesejahteraan masyarakat.

Dalam RUU pemda tersebut inovasi daerah merupakan hal yang penting mengingat diatur pada bab tersendiri sebagaimana tertuang dalam bab XIX mulai dari pasal 242245. Pada aturan tersebut dijelaskan bahwa dalam rangka meningkatkan pelayanan publik pemerintah daerah dapat melakukan inovasi yang merupakan semua bentuk pembaruan dalam penyelenggaraan pemerintahan daerah yang meliputi jenis, prosedur, dan metode pelayanan publik. Dalam hal pelaksanaan inovasi yang telah menjadi kebijakan pemerintahan daerah dan inovasi tersebut tidak mencapai sasaran yang telah ditetapkan, aparatur daerah tidak dapat diproses secara pidana sepanjang untuk tidak memperkaya diri sendiri atau orang lain.

Secara umum konsep inovasi berkaitan dengan karakteristik lingkungan yang selalu berkembang dan dinamis sehingga perlu adanyà ide atau pemikiran, praktek dan obyek yang dianggàp baru oleh individu atau organisasi (Rogers, 2003:12). Inovasi dapat dilihat sebagai metode kritis untuk meningkatkan kinerja pemerintah dan meningkatkan legitimasi kepada masyarakat. Inovasi pemerintah tidak lain adalah untukmenjaga perubahan aspirasi masyarakat yang cepat bagi sebuah pemerintahan yang efektif dan mampu merespon kebutuhan perubahan dari masyarakat modern. Inovasi harus lebih dari sekedar ide, inovasi adalah ideide baru dan bisa diimplementasikan, inovasi berbeda dengan penemuan. Inovasi dipahami dan diimplementasikan pada level organisasi dan melibatkan jaringan organisasi. Inovasi ini tidak hanya berfokus pada perubahan nyata dalam proses produksi tertentu, tetapi juga pada cara-cara di mana kegiatan produktif dibiayai, proses yang digunakan untuk memutuskan apa yang akan diproduksi, dan standar normatif yang digunakan untuk mengevaluasi kinerja dari sistem produksi dalam konteks sosial (Moore, 2010:52-57). Inovasi bisa berarti menggunakan cara kreatif dan cara yang tidak biasa dalam menyelesaikan masalah seperti misalnya dalam pelayanan dengan mengenalkan cara-cara pelayanan baru, merevisi visi misi, membentuk organisasi baru, dan mengembangkan proses-proses baru sebagai bentuk terobosan terhadap kebuntuan penyelesaian persoalan dan pelayanan. 
Inovasi di sektor publik dapat berkembang dan memperoleh tempat yang benar-benar kondusif pada paradigma new public management (NPM) karena pada paradigma ini banyak memberi ruang yang luas pada inovasi seperti halnya pada sektor bisnis. Secara umum NPM dipandang sebagai suațu pendekatan dalam administrasi publik yang menerapkan pengetahuan dan pengalaman dalam dunia manajemen bisnis untuk memperbaiki efisiensi, efektivitas dan kinerja pelayanan di sektor publik. NPM juga merupakan teori manajemen publik yang mengadopsi praktek manajemen bisnis yang dianggap lebih baik, lebih efisien dan lebih produktif (Syafri, 2012:169). Sebagai konsekuensi dari penerapan NPM ini masyarakat dianggap sebagai pelanggan (customer) yang harus dipuaskan oleh pemerintah sebagai penyedia pelayanan publik (provider). Di Indonesia praktek manajemen publik dengan. mengadopsi semangat sektor bisnis sudah banyak dilakukan dan memperoleh hasil yang cukup baik (Wibawa, 2005), namun demikian ada juga yang masih banyak menemui kendala. Kendala terbesar dalam implementasi NPM ini adalah belum adanya perubahan mindset dari aparatur daerah sebagai pemberi pelayanan dan partisipasi dari masyarakat yang belum semuanya siap dijadikan customer.

Dari paparan tersebut dapat diketahui bahwa untuk melakukan inovasi dalam kontek NPM ternyata tidak semudah membalik telapak tangan dan perlu adanya pemikiran ulang untuk merubah paradigma NPM ini, dan pada kajian yang lebih mutakhir pasca NPM ini sudah mulai dikembangkan paradigma baru yaitu new public governance (NPG). Sebagai suatu paradigma baru, NPG patut dijadikan wacana (discourse) dalam inovasi pemerintahan di Indonesia. Untuk melihat kemungkinan paradigma ini dipakai sebagai acuan dalam penyelenggaraan pemerintahan di Indonesia bisa dimulai dengan memahami terlebih dahulu apa itu NPM dan kemudian memotret bagaimana inovasi yang dilakukan oleh pemerintah Indonesia dalam kontek NPM beserta kendala yang dihadapi, hingga akhirnya dapat diketahui apakah perlu adanya perubahan paradigma inovasi di sektor publik berbasis new public governance (NPG).

\section{Konsep New Public Management Dan Inovasi Penyelenggaraan Pemerintahan}

Istilah New Public Management (NPM) awalnya dikenalkan oleh Christopher Hood (1991) sebagai suatu pendekatan manajemen moderen yang muncul di Eropa pada akhir tahun 1980-an atau awal tahun 1990-an sebagai reaksi terhadap administrasi publik (negara) yang tradisional, yang dinilai tidak efisien, tidak produktif, kurang inovatif, dan lain-lain; yang menurut Denhardt \& Denhardt (2003) disebut sebagai old public administratin (OPA). Fokus perhatian NPM adalah pada pelaksanaan desentralisasi, privatisasi, dan modernisasi pelayanan publik. Istilah lain dari NPM antara lain adalah managerialism (Pollit, 1993), marked-based public administration (Rossenbloom, 1992), post bureaucratic paradigm (Barzelay 1992), atau entrepreneural government (Osborne and Gaebler, 1992), namun yang sering dipakai adalah New Public Management. Secara umum NPM dipandang sebagai suatu pendekatan dalam administrasi publik yang menerapkan pengetahuan dan pengalaman dunia manajemen bisnis untuk memperbaiki efisensi, efektivitas, dan kinerja pelayanan publik pada sektor publik. NPM juga merupakan teori manajemen publik yang mengadopsi praktek manajemen swasta yang dianggap lebih baik, lebih efisien, dan lebih produktif. NPM juga sangat menitik beratkan pada mekanisme pasar dalam mengarahkan program-program publiknya.

Penerapan konsep NPM menyebabkan terjadinya perubahan mendasar pada administrasi publik yang dinilai kaku, birokratis dan hirarkis ke arah yang lebih fleksibel dan lebih mengakomodasi pasar. Konsep NPM dipandang sebagai bentuk reformasi atau modernsasi administrasi publik karena NPM menawarkan desentralisasi wewenang, depolitisasi kekuasaan sehingga mendorong demokrasi. Perubahan tersebut mengubah peran pemerintah terutama: dalam hal hubungan antara pemerintah dan masyarakat (Hughes, 1994). Pada perkembangan lebih lanjut NPM ini melahirkan reinventing government yang bersifat reformatif (Osborne, 1992). 
Karakteristik utama NPM adalah perubahan lingkungan birokrasi yang didasarkan pada aturan baku menuju sistem manajemen publik yang fleksibel dan lebih berorientasi pada kepentingan publik (Syafrie, 2012). Menurut pandangan NPM ini permasalahan birokrasi bukan muncul karena buruknya peraturan perundang-undangan dan kebijakan atau program, tetapi karena buruknya manajemen. Sehubungan dengan itu NPM merumuskan beberapa doktrin antara lain : berfokus pada manajemen bukan kebijakan, debirokratisasi, berfokus pada kinerja dan penilaian kinerja, akuntabilitas berbasis hasil, pemecahan birokrasi publik ke dalam unitunit kerja, penerapan mekanisme pasar melalui outsourcing untuk imembantu persaingan sektor publik, pemangkasan biaya, kompensasi berbasis kinerja, dan kebebasan manajemer dalam mengelola organisasi (Hughes; 1994; Vigoda 2003). Sedangkan reinventing government berisi hal-hal sebagai berikut: Pertama, pemerintah harus bersiat katalitik, berfokus pada pemberian arahan, bukan ikut campur mengerjakan sesuatu yang seharusnya dikerjakan sendiri oleh masyarakat, Kedua, pemerintah milik masyarakat sehingga pemerintah perlu memberdayakan masyarakat, bukan sekedar melayani; Ketiga, pemerintah perlu mendorong atau memunculkan semangat kompetisi dalam pemberian pelayanan publik; Keempat, pemerintah digerakkan oleh misi, mengubah pemerintah yang biasa digerakkan oleh peraturan menjadi organissi yang digerakkan oleh misi; Kelima, pemerintah berorientasi pada hasil dengan membiayai hasil; bukan masukan; Keenam, pemerintah berorientasi pada pemenuhan kepentingan pelanggan, bukan memenuhi kepentingan birokrasi itu sendiri; Ketujuh, pemerintah yang memiliki semangat wirausaha, bukan sekedar membelanjakan; Kedelapan, pemerintah yang antisipatif, lebih berupaya mencegah masalah daripada mengobati; Kesembilan, pemerintah yang terdesentralisasi (membagi kewenangan, dari hirarki menuju partisipasi dan kerjasama kelompok; dan Kesepuluh, pemerintah berorientasi pada mekanisme pasar, melakukan perubahan dengan mendongkrak (insentif), bukan dengan mekanisme administratif yang prosedural dan memaksa (Osborne dan Gaebler, 1992).

Pengalaman beberapa negara seperti AS khususnya di Departemen Rekreasi kota Philadelphia yang mulai menerapkan program inovasi dalam memberikan pelayanan publik, program yang dimaksud adalah dengan melakukan privatisasi beberapa urusan penyelenggaraan pelayanan publik khususnya pada penyediaan fasilitas rekreasi perkotaan. Beberapa perusahaan yang mempunyai program Corporate Social Responsibility diajak untuk melakukan kemitraan dan bersinergi dalam pengelolaan beberapa tempat rekreasi (Perlmutter, 1995). Demikian juga di kota New York dalam pengelolaan taman kota, pemerintah kota New York menjalin kemitraan dengan pihak pihak swasta. Di Massachusets pemerintah kota melakukan kontrak kerjasama dengan beberapa komunitas masyarakat dalam pelaksanaan program proteksi terhadap anak-anak yang kurang mampu (Moore, 2010:57-60).

Di Norwegia reformasi sektor publik dimulai tahun 1990-an yang pada intinya untuk menggganti monopoli publik dengan pasar yang kompetitif. Norwegian Planning And Building Act (NPBA) menjelaskan kewajiban dan tanggung jawab pelaksana/perusahaan swasta di sektor pembangunan dalam rangka mengurangi kerusakan yang diakibatkan oleh kesalahan perencanaan, desain, dan konstruksi. Sedangkan kewajiban pemerintah adalah harus mengontrol semua izin mendirikan bangunan/perumahan yang telah dikeluarkan. Amanat NPBA adalah adanya pergeseran dari publik ke swasta dimaksudkan supaya tanggung jawab, dan fungsi perencanaan pembangunan bergeser dari fungsi publik ke sektor swasta. Hal tersebut dianggap sangat relevan karena sektor swasta lebih menguasai desain dan konstruksi bangunan yang cocok dengan iklim, misalnya angin kencang, hujan salju, dan mencairnya es secara besar-besaran akibat pemanasan global (Eakin, 2011).

Di Inggris mulai tahun 2002 menerapkan program Local Government Modernisation Agenda (LGMA) atau penerapan e-Government di pemerintahan lokal. Program ini memiliki tujuan untuk meningkatkan kualitas pelayanan publik, pengembangan kapasitas pemerintahan 
lokal dan kepemimpinan, dan pengembangan elektronik government. Pada tahap awalnya program ini mengalami kendala di tingkat staff dan keterbatasan dana, namun perlahan-lahan kendala tersebut dapat diatasi. Keberhasilan ini sangat ditunjang oleh kepemimpinan lokal dengan komitmen yang kuat untuk menjalankan program tersebut (Martin, 2012).

Terdapat pelajaran penting dari pengalaman di ketiga negara tersebut dan banyak negara lainnya yang lebih berhasil dalam mengembangkan NPM. Dalam penerapan NPM di Indonesia secara khusus Fadel Muhammad (2008) menyusun beberapa agenda antara lain : reformasi birokrasi pemerintah daerah, menjalankan kebijakan yang digerakkan oleh pasar untuk memperkuat fondasi ekonomi rakyat, menjadi pemerintah yang katalis dengan memanfaatkan faktor endowment daerah untuk meningkatkan produksi pertanian, menyiasati hambatan lingkungan makro berupa kekakuan dari instansi pusat yang mengakibatkan daerah tidak mampu memanfaatkan potensi dan peluang bisnis di daerah, menjadikan pemerintah daerah yang berorientasi pelanggan dan pemerintah yang antisipatif, dan membangun keunggulan bersaing yang berbasis pada keunggulan lokal.

Untuk dapat meningkatkan kinerja pemerintah daerah dengan menerapkan prinsipprinsip NPM perlu adanya inovasi yang tertuang dalam kapasitas manajemen (Muhammad, 2008). Tawaran dari Moore (2010:64-68) patut dipertimbangkan bahwa inovasi di sektor publik harus berbeda dengan sektor bisnis, dimana inovasi di sektor publik harus : 1) menembus sekat-sekat organisasi dengan membuat sistem produksi berbasis jaringan, 2) mencari sumber daya baru dalam pembiayaan, material dan SDM, 3) memanfaatkan kapasitas pemerintah untuk meyakinkan, mendesak, dan mendefinisikan hak-hak pribadi dan tanggung jawab, 4) mendistribusikan hak untuk menentukan dan mempertimbangkan nilai apa yang sudah diproduksi, dan 5) mengevaluasi inovasi dalam hal keadilan, kewajaran, dan pengembangan masyarakat yang efisien dan efektif.

Implementasi NPM dalam suatu negara sebenarnya tidak harus mengadopsi secara keseluruhan bisa jadi hanya mengambil spirit atau sebagian dari prinsip-prinsip tersebut. Kepopuleran NPM ini seringkali mengaburkan makna dari manajemen publik itu sendiri, misal semangat swastanisasi diberi pengertian bahwa semua badan usaha pemerintah harus diswastakan, mestinya harus memilih badan usaha mana yang tidak efisien baru diswastakan, kalau masih sehat tidak perlu diswastakan. Demikian juga dalam pemberian pelayanan kepada masyarakat harus diukur dengan menggunakan angka indeks untuk mengetahui tingkat kepuasannya, mestinya harus dilihat jenis pelayanannya apakah masyarakat yang dimintai keterangan memang mengalami atau merasakan pelayanan yang diukur atau tidak.

Pengenalan NPM diharapkan akan membuat masyarakat dan birokrasi pemerintah mampu berhubungan secara lebih nyaman, berbiaya murah dan efektif terutama bagi pemerintah sebagai penyedia pelayanan. Beberapa penelitian menunjukkan bahwa aplikasi NPM tersebut membawa banyak perubahan dan peningkatan kinerja dalam penyelenggaraan pemerintahan daerah (Wibawa, 2005). Karena NPM merupakan paradigma yang secara ekstrim berbeda strukturnya dibandingkan dengan struktur birokrasi tradisional, penerapan NPM di negara berkembang seperti Indonesia akan terasa sulit dan sangat dibutuhkan adanya inovasi di berbagai bidang.

\section{Inovasi Penerapan NPM Di Indonesia}

Reformasi yang dimulai pada tahun 1998 nampaknya akan terus berlanjut dan belum menunjukkan titik akhirnya. Beberapa agenda reformasi yang telah dilaksanakan yang sebagian besar masih dalam bidang politik. Dalam melihat fenomena implementasi NPM di Indonesia ini Fadel Muhammad (2008) mencatat adanya tiga fenomena yang menonjol, yaitu sistem pemerintahan yang desentralistis, penilaian kinerja pemerintah dan privatisasi 
BUMN. Tonggak sejarah yang paling nyata dalam implementasi NPM di Indonesia adalah dengan pemberlakuan sistem pemerintahan yang desentralistis lewat Undang-undang Nomor 22 tahun 1999 tentang Pemerintah Daerah yang kemudian diubah dengan Undangundang Nomor 32 tahun 2004. Kedua undang-undang tersebut memberi penekanan pada pemberian kewenangan seluas-luasnya kepada daerah agar daerah memiliki kewenangan membuat kebijakan untuk pelayanan, peningkatan peran serta, prakarsa dan pemberdayaan, dengan mengutamakan kesejahteraan masyarakat di daerah.' Dalam menjalankan sistem pemerintahan yang desentralisitis ini pemerintah daerah diserahi otoritas untuk menjalankan pelbagai urusan.

Implementasi doktrin NPM juga dapat dilihat dari kewajiban bagi pemerintah daerah untuk melakukan penilaian kinerjanya. Seperangkat aturan diberlakukan antara lain melalui Peraturan Pemerintah (PP) Nomor 108 tahun 2000 tentang Tata Cara Pertanggungjawaban Kepála Daerah, PP Nomor 105 tentang Pengelolaan dan Pertanggungjawaban Keuangan Daerah, dan kemudian dilanjutkan dengan PP Nomor 56 Tahun 2002 tentang Laporan Kinerja Penyelenggaraan Pemerintahan Daerah dan PP Nomor 20 Tahn 2004 tentang Rencana Kerja Pemerintah. Dalam level unit kerja di SKPD pemerintah daerah juga diwajibkan untuk menyusun Laporan Akuntabilitas Kinerja Instansi Pemerintah (LAKIP) setiap tahun. Demikian juga dalam penyusunan rencana kegiatan dan anggaran menggunakan sistem anggaran yang berbasis kinerja.

Doktrin NPM ini juga terimplementasi dengan pemberlakuan peraturan perudangan tentang privatisasi di Indonesia seperti Keppres Nomor 122 Tahun 2001 tentang Tim Kebijakan Privatisasi BUMN. Tujuannya untuk meningkatkan kinerja BUMN yang meliputi perbaikan struktur permodalan, meningkatkan profesionalisme dan efisiensi usha, perubahan budaya perusahaan, memperluas partisipasi masyarakat dalam kepemilikan saham BUMN serta pencapaian nilaj tambah perusahaan melalui penerapan prinsip good corporate governance yang didasarkan pada transparansi, akuntabilitas dan kemandirian (Muhammad, 2008).

Disamping ketiga fenomena tersebut sebenarnya masih banyak praktek penyelenggaraan pelayanan publik yang terinspirasi dari doktrin NPM ini. Standarisasi pelayanan publik merupakan salah satu program yang gencar dilaksanakan oleh pemerintah, mulai dari sertifikasi pelayanan melalui ISO 9000, standar pelayanan minimal (SPM), kontrak pelayanan (citizen charter), pengukuran indeks kepuasan masyarakat dan penyatuan pusat pelayanan dalam satu kantor atau satu atap. Terdapat juga berbagai inovasi penyelenggaraan pemerintahan yang dilakukan, mulai dari tata kelola pemerintahan hingga sampai penyusunan analisis jabatan dan beban kerja yang dilakukan sebagaimana perusahaan swasta.

Doktrin NPM ini juga direspon dalam bentuk electronic government (e-gov), sebagian besar pemerintah daerah sudah menggunakan teknologi informasi untuk mendukung penyelenggaraan pemerintahan. Pemanfaatan teknologi internet oleh pemerintah daerah di Indonesia menunjukkan perkembangan yang cukup pesat. Hal ini terlihat dari jumlah pemerintah daerah yang telah memiliki website hingga tahun 2012 sudah mencapai $90 \%$ (Kompas, 28 November 2012). Disamping pemanfaatan website untuk desiminasi kebijakan dan informasi sekarang sudah mulai dikembangkan menjadi media untuk pengadaan barang/ jasa (e-procurement) agar bisa dicapai azas transparansi dan akuntabilitas.

\section{Permasalahan Dan Kendala Yang Dihadapi}

Setelah berlangsung beberapa tahun, desentralisasi yang dijalankan pemerintah sebagai wujud dari penerapan NPM ternyata sering menyebabkan konflik berkepanjangan antara pemimpin lokal dan nasional dalam memperebutkan komoditi suatu daerah (Palmer, 2007). Munculnya "raja-raja kecil" di daerah semakin jauh dari semangat NPM, demikian juga 
banyak kepala daerah yang tersangkut dalam kasus korupsi, malah sekarang ada wacana untuk resentralisasi kembali. Banyak kalangan menilai bahwa desentralisasi dan demokratisasi tersebut kebablasan. Dalam beberapa hal banyak kepala daerah juga tidak bisa menjadi agen. implementasi kebijakan pemerintah pusat, kasus wakil walikota Surakarta (Suara Merdeka, 12 Januari 2012) yang turun ke jalan karena menolak kenaikan harga BBM merupakan salah satu contoh.

Penilaian kinerja sebagai salah satu bentuk implementasi NPM juga masih menemui kendala, secara formal pemerintah daerah sudah menyusun laporan kinerja sesual dengan peraturan yang ditetapkan, namun pelaporan masih sebatas pada "menggugurkan kewajiban" belum menjadi bagian yang komprehensif dari sistem akuntabilitas publik. Demikian juga tindak lanjut dari laporan tersebut belum menunjukkan hal yang menggembirakan. SKPD di daerah setiap tahun menyusun LAKIP tetapi tidak ada kelanjutannya bahwa laporan tersebut akan dijadikkan bahan evaluasi untuk perencanaan di tahun berikutnya. Penyusunan anggaran dengan berbasis kinerja sudah dilakukan tapi masih sebatas pada "upacara" penyusunan anggaran belum menyentuh pada hal yang bersifat substansial dan sebagai instrumen pemecaham masalah publik. Permasalahan penilaian kinerja tersebut apabila dilihat dari sistem yang ada sudah cukup baik namun perlu adanya penegakan aturan dan disertai monitoring yang cermat dari pemimpin organisasi.

Privatisasi BUMN sempat menjadi isu nasional merupakan bentuk implementasi dari NPM di Indonesia. Privatisasi BUMN banyak dilakukan pada waktu Megawati menjadi presiden dan Laksamana Sukardi menjadi menteri BUMN. Banyak kontroversi dalam privatisasi BUMN. pada waktu itu, tuduhan pada rezim waktu itu pemerintah banyak menjual aset negara kepada swasta (Kompas, 3 Maret 2002) dan setelah tidak menjadi menteri Laksamana Sukardi sempat diperkarakan di pengadilan.

Dalam bidang pelayanan publik secara umum sudah mulai nampak ada peningkatan yaitu dengan mulainya diterapkan standarisasi pelayanan publik. Dengan adanya standarisasi ini diharapkan dapat meningkatkan akuntabilitas dan juga transparansi pelayanan publik. Masyarakat bisa memperoleh pelayanan yang standar sesuaj dengan apa yang menjadi janji dari pemerintah daerah. Berbagai instrumen mulai dikembangkan namun persoalan yang mengemuka adalah kurangnya kesamaan antara daerah dalam menentukan standar sehingga banyak investor yang memilih-milih lokasi untuk investasi (Dwiyanto, 2002). Antar daerah mempunyai mekanisme dan prosedur yang berbeda sehingga menyulitkan bagi pihak swasta yang akan melakukan kerjasama. Praktek pengukuran kualitas pelayanan sudah dilakukan di setiap daerah dengan menghitung nilaj indeks kepuasan namun pada kenyataannya masih bersifat subyektif dan adakalnya dilakukan oleh pemerintah itu sendiri, tentu saja hasilnya mudah ditebak bahwa masyarakat merasa puas untuk dilayani.

Aplikasi teknologi informasi dalam penyelenggaraan pemerintahan (e-government) masih juga menghadapi kendala, banyak faktor yang menyebabkan antara lain adalah terkait dengan belum memadainya kapasitas SDM pengelola teknis, keterbatasan infrastruktur pendukung; masih lemahnya regulasi dan kelembagaan, terbatasnya dukungan anggaran pemerintah, serta masih rendahnya komitmen dan keseriusan dari para pemimpin (Purbokusumo, 2010). Sementara di kalangan masyarakat sendiri juga masih banyak yang belum mampu mengakses media elektronik terutama internet, baik karena rendahnya pengetahuan dan tingkat mejek warga terhadap teknologi informasi maupun karena keterbatasan ekonomi sehingga belum banyak yang menjadikan internet sebagai sumber informasi, atau bahkan informasi belum dianggap sebagai kebutuhan penting bagi mereka. 
UNISIA, Vol. XXXIV No. 77 Juli 2012

\section{Perlunya Paradigma Baru}

Dari berbagai praktek penyelenggaraan pemerintahan yang menggunakan spirit NPM ternyata masih banyak menimbulkan kendala dan bahkan ada yang mempunyai dampak bersifat negatif (Purwanto, 2010), disamping itu ada beberapa pakar yang masih meragukan keampuhan NPM ini. NPM dinilai kurang memperhatikan keadilan sosial karena menempatkan masyarakat sebagai customer bukannya citizen (Denhardt \& Denhardt, 2003), dan kurang berhasil mengelaborasi kemitraan antara warga negara, pemerintah dan sektor swasta (Vigoda, 2003).

Apa yang menjadi keraguan dari pakar tersebut ternyata di Bangladesh dan negaranegara Afrika menjadi kenyataan (Syafri, 2012:172). Tidak kurang di negara maju seperti Norwegia dan Mexico juga menemui kendala (Moore,2010), bahkan NPM sekarang sudah banyak menuai kritik. Osborne (2010:4) mengidentifikasi beberapa kritik yang disampaikan oleh beberapa pakar yang berkaitan NPM ini, yaitu: NPM bukan merupakan sebuah fenomena atau paradigma tetapi hanya merupakan suatu kluster (Ferlie dkk, 1996), wilayah berlakunya NPM tidak universal tetapi terbatas pada wilayah Anglo-Amerika, Australia, beberapa negara Skandinavia dan beberapa negara lain (Kickert, 1997 dan Hood, 1995), sifat NPM itu sendiri yang berbeda secara geografi misalnya Amerika Serikat dan Inggris yang benar-benar berbeda satu sama lain baik dalam lokus maupun fokusnya (Borins, 2002), NPM pada kenyataannya adalah hanya sub mazhab dalam administrasi publik yang memiliki pengaruh terbatas akibat kekurangan dasar teoritis dan konseptual (Frederickson dan Smith, 2003), kemanfaatan NPM bersifat parsial, "tidak universal", dan masih perlu uji coba (Pollit dan Bouckaert, 2004), NPM merupakan "bencana yang menunggu untuk terjadi" (Hood dan Jackson, 1992) dan "paradigma yang.gagal" (Farnham dan Horton, 1996).

Meskipun beberapa pakar tersebut menganggap bahwa NPM bukan merupakan paradigma tetapi kalau mengacu pada apa yang dikemukakan oleh Thomas Kuhn (2006) NPM dapat disebut sebagai paradigma karena merupakan model yang didukung oleh banyak pakar dan mempunyai daya penjelas serta bermanfaat untuk menjadi alternatif baru dalam memecahkan masalah besar dalam bidang ilmu Administrasi Publik. Paradigma ini akan bergeser apabila pada perkembangannya dihadapkan pada anomali atau penyimpangan, paradigma tersebut tidak mampu untuk menjelasan fenomena yang terjadi atau tidak mampu untuk mengatasi persoalan yang berkembang. Dengan melihat dari berbagai kendala implementasi NPM dan kritik yang sangat tajam dari para pakar maka perlu adanya paradigma baru untuk memecahkan masalah tersebut.

Paradigma baru yang muncul sebagai kelanjutan dari NPM ini antara lain adalah new public service/NP's (Denhardt \& Denhardt, 2003) dan new public governance/NPG (Osborne, 2010). NPS menilai bahwa NPM terlalu menekankan pada efisiensi dan melupakan atau mengabaikan masyarakat sebagai sasaran dari kebijakan publik. NPS memperbaiki kekurangan ini dengan konsep pelayanan kepada warga masyarakat bukan kepada pelanggan (delivery service to citizen not customer) dalam proses penyelenggaraan administrasi publik dan kebijakan publik. Menurut pendekatan NPS, administrasi publik tidak bisa dijalankan seperti perusahaan bisnis sebagaimana yang dikehendaki dalam NPM karena administrasi negara harus mampu menciptakan suasana demokratis dalam seluruh proses kebijakan publik, yaitu dengan memperhatikan kepentingan dan nilai-nilai yang hidup di kalangan masyarakat. Paradigma NPS ini lebih banyak menekankan pada kebijakan dan pelayanan publik, dalam kontek inovasi penyelenggaraan pemerintahan paradigma NPS ini perlu dikembangkan menjadi NPG untuk dapat memberi penjelasan tentang peran dari stakeholders secara komprehensif.

Paradigma NPG yang dikembangkan darikonsep public governance, dimana pendekatan ini menunjuk pada saling interaksi antara para stakeholders dengan tujuan mempengaruhi 
hasil kebijakan (Bovaird \& Loffler, 2009). Stakeholders tersebut meliputi antara lain masyarakat (warga negara), organisasi masyarakat, organisasi swasta, lembaga publik, media massa, organisasi nirlaba, kelompok kepentingan, dan sebagainya.

Public Governance berisi lima untaian berikut (Osborne, 2010:6-7) : Pertama, Sociopolitical governance, menyangkut hubungan antar institusi dalam masyarakat. Kooiman (1999) mengatakan bahwa hubungan timbal balik dan interaksi antar institusi dalam masyarakat perlu dipahami secara totalitas dalam pembuatan ataupun implementasi kebijakan publik. Dalam konsep demikian, pemerintah tidak lagi menjadi dominan dalam pembuatan kebijakan publik, tetapi bergantung kepada keseluruhan komponen masyarakat (stakeholders). Kedua, Public policy governance, berkaitan dengan bagaimana elite pembuat kebijakan beserta jaringannya: berinteraksi dalam proses pembuatan dan pelaksanaan kebijakan publik. Ketiga, Administratif governance, menyangkut efektivitas penerapan administrasi publik dan reposisinya untuk menangani masalah-masalah pemerintahan yang dewasa ini semakin kompleks. Keempat, Contract governance, berkaitan dengan penerapan NPM, dipandang perlu adanya kontrak perjanjian dalam penyelenggaraan pelayanan publik (perjanjian antara penyedia pelayanan publik dengan pihak penerima layanan). Dan kelima, Network govemance, merupakan jaringan kerja sama mandiri antar organisasi pemerintah atau tanpa organisasi pemerintah dalam penyediaan pelayanan publik.

Munculnya paradigma baru ini meskipun tidak selalu menghilangkan paradigma lama, patut dijadikan wacana inovasi penyelenggaraan pemerintahan daerah. Inovasi dalam kontek NPG ini diharapkan dapat mengatasi kendala dan dampak negatif yang ditimbulkan oleh NPM. Beberapa hal yang menonjol dari NPG ini adalah adanya konsep tentang kolaborasi dan jaringan yang didasari oleh kontrak diantara ketiga pilar governance.

\section{Paradigma New Public Governance Sebagai Basis Inovasi}

Kendaladan permasalahan yang ditimbulkan dari inovasi penyelenggaraan pemerintahan berbasis NPM diharapkan dapat diselesaikan dengan penerapan paradigma NPG ini. Prinsipprinsp NPG yang telah dikemukakan tersebut dapat dicoba untuk mencari solusi permasalahan. yang ditimbulkan oleh NPM tersebut. Untuk kasus inovasi kebijakan desentralisasi NPG menawarkan prinsip adanya public policy governance, dimana antara pemerintah pusat dan pemerintah daerah menjalin hubungan yang sinergis agar ada keseimbangan antara pusat dan daerah. Persoalan kepentingan antara pusat dan daerah yang bernilai negatif dapat dieliminasi atau ditransformasi menjadi sebuah kerjasama yang produktif diantara para aktor di berbagai level daerah apabila dikelola oleh kelembagaan dan kepemimpina yang kolaboratif.

Inovasi tentang penilaian kinerja sebagai wujud dari akuntabilitas yang selama ini menemui kendala karena kurang adanya tindak lanjut dan sebatas pada seremonial dapat diselesaikan dengan prinsip contract governance yang berwujud kontak kinerja. Kinerja bisa dalam arti unit kerja organisasi dan individu. Sistem penilaian kinerja perlu disempurnakan dengan mempertimbangkan penilaian yang berdimensi "360 derajat" dengan melibatkan atasan, bawahan dan teman sejawat. Perlu adanya reward diantara unit kerja yang mempunyai prestasi dan mungkin dipertimbangkan untuk memberi punishment bagi yang sama sekali tidak mempunyai prestasi.

Swastanisasi yang banyak menemui kendala bisa diselesaikan dengan melakukan dialog yang intensif dan studi yang mendalam mengenai BUMN yang bermasalah, pertimbangan tidak hanya sekedar efisiensi tetapi juga melihat bagaimana kemanfaatan BUMN tersebut dalam pemberikan pelayanan publik. Social-politic governance menjadi pertimbangan utama. karena BUMN tidak sekedar perhitungan untung rugi. 
UNISIA, Vol. XXXIV No. 77 Juli 2012

Inovasi di bidang pelayanan publik dalam paradigma NPM karena menempatkan masyarakat sebagai pelanggan, karena pelayanan publik bersifat monopoli maka tidak tepat kalau masyarakat diposisikan sebagai pelanggan. Masyarakat sering tidak mempunyai pilihan dalam menerima pelayanan. Pelanggan dapat memilih mana jenis pelayanan yang disukai dan mempunyai keleluasaan, oleh karena itu lebih tepat kalau masyarakat diposisikan sebagaj warga negara yang mempunyai hak untuk memperoleh pelayanan yang memuaskan. Contract governance dan network governance dapat dijadikan sebagi solusi karena ada proses demokratisasi pelayanan dan mengurangi ego sektoral terutama dalam pelayanan perijinan.

Penerapan e-government sebagai simbul dari inovasi dalam kontek NPM mengalami kendala karena masyarakat kurang berdaya dan kesulitan memperoleh akses. Pada paradigma NPG akan teratasi apabila masyarakat diberdayakan dan terjadi network diantara pilar governance. Pelayanan publik yang berbasiskan IT (information technology) perlu dikaji lebih dahulu agar mudah diakses masyarakat, kalau perlu dibuat kontrak pelayanan (citizen's charter) yang memberi kesempatan masyarakat untuk berpartisipasi baik dalam penyusunan metode dan cara memberi pelayanan. Kepastian dalam menentukan biaya, waktu dan prosedur melibatkan seluruh warga negara (citizens).

\section{Kesimpulan}

Setelah melakukan elaborasi terhadap berbagai teori governance dan memahami paradigma yang ada, inovasi penyelenggaraan pemerintahan dapat dilakukan dengan berbasis pada paradigma tertentu. Paradigma New Public Governance (NPG) menjadi sangat relevan untuk menyongsong diberlakukannya undang-undang pemerintahan daerah yang baru. Meskipun demikian karena cakupan inovasi begitu luas tidak menutup kemungkinan ada beberapa praktek inovasi yang masih cocok dan sesuai dengan paradigma lama (NPM), atau tidak menutup kemungkinan masih relevan dengan paradigma old public administration (OPA).

\section{Daftar Pustaka}

Anderson, K.V. 2006. "e_Government: Five key challenges for management", in The Electronic Journal of e-Government, Vol. 4, Issue 1, pp. 1-8.

Barzelay, Michael, 1992. Breaking Through Bureaucracy, Berkeley: University of California Press.

Bovaird, T and Loffler E (ed), 2009. Public Management and Governance, London: Routledge. Denhardt, Robert B and Janet V Denhardt. 2003. New Public Service, Serving Not Steering, Expanded Edition, New York: M.E. Sharpe.

Dwiyanto, Agus, 2002. Reformasi Birokrasi Publik di Indonesia. Yogyakarta : Pusat Studi Kependudukan dan Kebijakan Universitas Gadjah Mada.

Eakin, Hallie, Siri Erikśen, Per-Ove Eikeland and Cecilie Oyen, 2011, "Public Sector Reform and Governance for Adaptation: Implication of New Public Management for Adaptive Capacity in Mexico and Norwey", in Environmental Management Journal 47, p. 338-351.

Hoods, C. 1991. "A Public for All Season, in Public Administration, vol. 69, p. 3-9.

Hughes, Owen. 1994. Public Management and Administration: An Introduction, NewYork: Saint Martin Press.

Kooiman, Jan. (ed), 1999, Modern Governance: New Governement-Society Interaction, London: SAGE Publication.

Kuhn, Thomas, 2006, The Structure of Scientific Revolutions, (Terjemahan), Bandung: Alfabeta. 
Martin, S.J. 2002. "The Modernisation of UK Local Government", in Public Management Review, Vol. 4, No. 3, pp 1-15.

Moore, Mark and Jean Hartley, 2010. "Innovations in Governance", in Stephen P. Osborne, The New Public Governance ? Emerging Perspective on the Theory and Practice of Public Governance, London \& New York: Routledge.

Muhammad, Fadel. 2008, Reinventing Local Government, Pengalaman Dari Daerah, Jakarta: Elex Media Komputindo.

Olsen, Johan P. 2004 "Citizen, PublicAdministration and the Search for Theoretical Foundations," PS: Political Science and Politics 37, pp. 69-73.

Osborne, David and Ted Gaebler, 1992. Reinventing Governement, Reading MA: Harvard University Press.

Osborne, Stephen P, 2010. The New Public Governance ? Emerging Perspective on the Theory and Practice of Public Governance, London \& New York: Routledge.

Pollit, Christopher, 1993, Managerialism and Public Services: The Anglo-American Experience, 2nd Edition, Oxford: Blackwell.

Pollit, Christopher \& G. Bouckaert, 2004. Public Management Reform: A Comparative Analysis, Oxford : Oxford University Press.

Purbokusumo, Yuyun, 2010. "Kepemimpinan Entrepreneur Di Era E-Government", dalam Erwan Agus Purwanto, Reformasi Birokrasi, Kepemimpinan dan Pelayanan Publik, Yogyakarta: Gava Media.

Purwanto, Erwan dan Agus Pramusinto (ed), 2008, Reformasi Birokrasi, Kepemimpinan dan Pelayanan Publik, Yogyakarta: Gava Media.

Rogers, E.M. 2003. Diffusion of Innovations, New York: Free Press.

Ruhyanto, Arie, 2012. "RUU Pemda dan Inovasi Daerah", dalam University Network for Inovative Governance, Yogyakarta: Fisipol UGM.

Syafri, Wirman. 2012. Studi Tentang Administrasi Publik, Jakarta: Erlangga.

Wibawa, Samodra, 2005, Peluang Penerapan New Public Management Untuk Kabupaten di Indoensia, Yogyakarta: Gadjah Mada University Press.

Vigoda, Eran (ed), 2002. "The Legacy of Public Administration: Background and Review", in Public Administration: An Interdiciplinary Critical Analysis, New York: Marcel Dekker Inc.

Undang-undang Nomor 22 Tahun 1999 tentang Pemerintahan Daerah

Undang-undang Nomor 32 Tahun 2004 tentang Pemerintahan Daerah

Peraturan Pemerintah (PP) Nomor 108 tahun 2000 tentang Tata Cara Pertanggungjawaban Kepala Daerah.

Peraturan Pemerintah Nomor 105 tentang Pengelolaan dan Pertanggungjawaban Keuangan. Daerah,

PP Nomor 56 Tahun 2002 tentang Laporan Kinerja Penyelenggaraan Pemerintahan Daerah.

\section{PP Nomor 20 Tahn 2004 tentang Rencana Kerja Pemerintah.}

Keppres Nomor 122 Tahun 2001 tentang Tim Kebijakan Privatisasi BUMN.

Kompas, 27 Desember 2012 
UNISIA, Vol. XXXIV No. 77 Juli 2012

Suara Merdeka, 12 Januari 2012

Kompas, 23 Desember 2011 